International Journal of Korean Humanities and Social Sciences

Vol. 5/2019

DOI: http://dx.doi.org/10.14746/kr.2019.05.03

\title{
EAST ASIA, THE RESTORATION OF MEMORIES AND NARRATIVE OF RETURN $^{1}$
}

\section{SUYUN RYU, Prof.}

\author{
Inha University, Frontier College \\ 100 Inha-ro, Michuhol Gu, Incheon, South Korea \\ mynamecat@inha.ac.kr
}

ORCID: https://orcid.org/ 0000-0003-2217-4602

\begin{abstract}
In the early 2000s, Hwang Seok-young published three full-length novels. They were The Old Garden (2000), The Guest (2001) and SimCheong (2003). The return trilogy attracted much attention in that they were works that informed Hwang Seok-yeong's return to the Korean literary world. He visited North Korea in 1989 and exiled in Germany until 1993. He was imprisoned shortly after returning home in 1993 and imprisoned until 1998. Conflict and anguish due to his personal history overlap in the three works. It was the thematic focus of 'return'. 'Return' is not simply returning. Above all, it is an encounter with 'self-absence' and is the most positive return to think of 'today'. Furthermore, the final goal is to reconcile with the present. Therefore, the three long-time narratives he published were Hwang Seok-young's return process as a writer.
\end{abstract}

\footnotetext{
${ }^{1}$ This paper was researched with the support of Inha University.
} 
Key words: Hwang Seok-yeong; return trilogy; The Old Garden (2000); The Guest (2001); Sim-Cheong (2003); Galmoe; The Sincheon Massacre; Simcheong-Jeon.

\title{
동아시아, 기억의 복원과 서사의 귀환
}

초록: 황석영은 세 권의 장편소설을 출판했다. 오래된 정원 (2000), 손님 (2001), 심청 (2003) 이 그것이다. 이 귀환 3부작은 황석영의 한국 문학계로의 복귀를 알리는 작품이라는 점에서 많은 관심을 끌었다. 그는 1989년 북한을 방문했고, 독일로 망명하여 1993년까지 있었다. 1993년 귀국 직후 체포되어 1998년까지 수감되었다. 이러한 그의 개인사로 인한 갈등과 고뇌는 세 작품 위로 겹쳐진다. 그 초점은 바로 '귀환'이었다. '귀환'은 단순히 돌아오는 것을 의미하는 것이 아니다. 무엇보다 그것은 '자기 존재'와의 만남이며, '오늘'이라는 사유 속으로 가장 능동적으로 복귀하는 것이다. 더 나아가 그 최종 목표는 바로 현재와 화해하는 것이다. 따라서 그가 발표한 세 편의 장편소설은, 그의 작가로서 복귀 과정을 담아내고 있다.

주제어: 황석영; 귀환 3부작; 오래된 정원 (2000); 손님 (2001); 심청 (2003); 갈뫼; 신천대학살; 심청전.

\section{AZJA WSCHODNIA, NARRACJA POWROTU ORAZ PRZYWRACANIE PAMIECI}

\begin{abstract}
Abstrakt: Hwang Seokyeong opublikował na początku wieku XXI trzy powieści: Stary ogród (2000), Gość (2001) oraz Sim-cheong (2003). Powieści te prezentowały powrót Hwang Seok-yeonga do świata twórczości literackiej, stąd przykuły uwagę czytelników jako trylogia powrotu. Hwang był w 1989 roku w Korei Północnej a następnie aż do roku 1993 przebywał na wygnaniu w Niemczech. Krótko po powrocie do kraju w 1993 został uwięziony na pięć lat. Powieści te przesycone są konfliktem i udręką spowodowanymi osobistymi doświadczeniami. To właśnie stało się motywem przewodnim 'powrotu'. 'Powrót' nie polega jedynie na ponownym przybyciu - jest to przede wszystkim zetknięcie się z własną 'nieobecnością', skłania także do pozytywnego podejścia do 'dzisiaj'. Celem jest przecież pogodzenie się z teraźniejszością. Te trzy powieści obrazują proces powrotu Hwang Seok-yeonga do twórczości literackiej.
\end{abstract}

Stowa klucze: Hwang Seok-yeong; Trylogia Powrotu; Stary ogród (2000); Gość (2001); Sim cheong (2003); Galmoe; Masakra w Sincheon; SimcheongJeon. 


\section{A Topic of 'Return'}

This article is written in the text based in Hwang Seok-yeong's three novels which were published in the early 2000s: The Old Garden (오래된 정원) (2000), The Guest (손님) (2001), Sim-Cheong (심청) (2003). Hwang visited North Korea in 1989, but he could not return to South Korea. He went straight to Germany and lived in exile until 1993. He returned to the South after the regime was replaced in 1993, but he was sentenced to five years for imprisonment for violating the National Security Law. His personal history is reflected in these novels. The topic that covers these three works is 'Return', so I named them as the 'return trilogy'. Translations into English are mine.

In fact, the theme of return is not so strange in Hwang's novels. His major works, such as The Road to Sampo, Jang Gil-san, The Shadow of Weapons, also dealt with the issue of return as an important topic. Still, another reason to note the theme of 'returns' in the three long novels published in the 2000s is that there is a significant change in the way they are returned. What attracts attention here is the confusion of identity. Return is not just come back. Above all, it is a encounter with 'self absent' and is the most active come back for 'today'. Furthermore the final goal is to be reconciled with the present. As a result, Hwang Seok-young's return trilogy were also process of his return as a writer.

\section{Call to a Place of Memory -The Old Garden}

The Old Garden is Hwang's first work since his release. Therefore, it is worth noting that is a work that declares his actual return. Faced with Hwang's autobiographical life, the work begins with the return of Oh Hyun-woo, who has been imprisoned for 18 years. The character, Oh Hyun-woo, who lived the most fiercely in the 80s, is more like a reenactment of the "ideological critical subject"2 (오태호 Oh Tae-ho 2005b: 276) which previously appeared in Hwang Seok-young's novel. It evokes familiar fictional experiences that have been revealed in established epilogue novels.

2 “이데올로기 비판적 주체” 
However, Hwang's interest in The Old Garden is not in the process of returning or conflicts after her return. Rather, he has built his narration on 'the absence' until the return was possible. This is based on the perception that the contradictions of the time that the returner should resolve are not the present he encountered but the time of the past when he was absent. Therefore, the narrative core of The Old Garden lies not in the return itself but in the past, more precisely, in the memory of the return. In fact, the problem of the returnees' confusion is not unfamiliar to Hwang's novels. Already, he has exemplified this problem in his "Path to Sampo" which has been interpreted as his willingness to overcome the gap between the present and the hometown as an ideal (cf. 강용훈 Kang Yong-hoon 2007: 260). However, the way Oh Hyun-woo faces his past in The Old Garden is very unique. His past is not described by himself, but it is developed through the record of Han Yoon-hee's letter. Despite the fact that epic time is based on Oh's reality, the most interesting story in the work is told through Han's record. Han's letter is "a novel written in the form of a letter and a series of letters developed with the framework of the novel"3 (오생근 Oh Saeng Geun 2003: 83).

The first change shown by Hwang Seok-young as writer who returned to Korean society, is a strong belief in records. The memory that is presented through the record of a letter in The Old Garden gives the main character Oh Hyeon-woo a necessity for his return. But it is also the answer to the author Hwang Seok-young's return. $\mathrm{He}$ seems to believe that reenactment of past memories through records can give a vivid, fictional sense of realism. The Old Garden becomes an imaginary text that will fill Hwang's absence in Korean society. This means that The Old Garden is 'an imagine existence (상상된 현존 [現存])' that will fill the absence of Hwang in Korean society.

In this work, however, the space that drives the presentization of memories is none other than Galmoe. Galmoe is a space where alive Oh Hyeon-woo and dead Han Yoon-hee meet through their documented memories of a letter. In other words, he overcame the time he was absent for 18 years and faced Han Yun-hee's past. As such, the meeting of an absence and another absence allow for a more intense virtual sense of existence. So despite the fact that narrative

3 “편지의 형식으로 씨어진 소설이고, 소설의 골격을 갖추어서 전개된 편지의 연속” 
time is based on Oh's present, the most interesting story in this work actually becomes Han's letter.

Han's letter embodies the meaning of his return. It's a record, first of all, and the 'power of memory' shown by that record. Han Yoon-hee recorded the life of reality as if to fill Oh's absence who was in prison. Through Han's record (a letter) Oh Hyun-woo collects pieces of time he was away from. A person's memory is absorbed into another person's memory through records and is brought to life. As such, the writer Hwang Seok-young shows that records can be a force to reconstruct reality. This is more of a confidence in himself as a writer. For him, fiction is a recovery of his absence, which in turn leads to reconciliation with the present. Now I try to focus on Galmoe again. It is the place where the conversation between the living and the dead takes place through this record, and the space of contact that exists beyond the boundary of reality.

In a previous study of The Old Garden, Galmoe has received the attention of many researchers (cf. 강용훈 Kang Yong-boon 2007; 권경미 Kwon Kyong-mi 2013; 남진우 Nam Jin-woo 2000; 오생근 Oh Saeng Geun 2003; 오태호 Oh Tae-ho 2005). Generally speaking, Galmoe was interpreted as maternal utopia. In response, 권경미 Kwon Kyong-mi (2013: 214) said:

\begin{abstract}
"One possible reason in interpretation of Galmoe as Utopia is the strong consensus that this novel is a memorial to the frustration and failure experienced by the previous generation of intellectuals represented by Oh Hyun-woo."4
\end{abstract}

"Where are you going now? - Just follow me. It's Paradise (武陵桃源)" 5 (황석영 Hwang Seok-yeong 2000: 60)

Galmoe's character as Utopia was inspired by Han's words. In her first meeting with Oh Hyeon-woo, she refers to Galmoe as 'Mureung Dowon (武陵桃源)'. It has affected reading of The Old Garden for quite a long time. Obviously, in this work, Galmoe is Utopia, but it isn't absolute. If Galmoe was Utopia for Han, it is

\footnotetext{
4 “유토피아로서의 ‘갈뫼’라는 해석의 일변도가 가능한 이유는 이 소설이 ‘오현우'로 대변되는 이전 세대의 지식인들이 겪었던 좌절과 실패에 대한 위무(慰搤)라는 강한 동의가 뒷받침되어 있기 때문".

5 “지금 어디루 가는 거요? - 따라만 오세요. 무릉도원이니까."
} 
Suyun RYU: East Asia, the Restoration of Memories...

because the meaning is more complex for the main character $\mathrm{Oh}$ Hyeon-woo:

"Being underground means that a revolutionist breaks himself and his surroundings at once and enters the lives of people without his own face. He has no name and no character". ${ }^{6}$ (황석 영 Hwang Seok-yeong 2000:170)

"Escape itself is a main activity for a refugee. He is like, for example, a carrier of infectious diseases that can spread danger around him. Therefore, he must isolate himself and fight with himself until there is safe."7 (황석영 Hwang Seok-yeong 2000:171)

To Oh Hyeon-woo, a wanted man, Galmoe was not a voluntary option but a place of escape. There was "a space that was expelled from reality and, by extension, a space that made the sense of helplessness against itself." (cf. 권 경미 Kwong Kyong-mi 2013: 212213). In other words, it was more like "a space of exile and asylum." (2013: 218).

However, Han's letter unites Galmoe, which was opposed to Han Yoon-hee and Oh Hyeon-woo in different meanings. At the moment of her death, she declares returning to Galmoe to her sister Jeong-hee. Such her will and letter lead to the transformation of the nature of Galmoe into a place where life and death meet. It made Galmoe into a place of spirituality.

"It was. When I reached the top of the mountain, I felt like I was going to burst because of the frustration that I was isolated. While they flourished with force and violence, my dead friends were secretly rotting under shallow ground surrounded by the family's breathless cries." (황석 영 Hwang Seok-yeong 2000:216)

\footnotetext{
6 “활동가가 지하에 들어간다는 것은 다름 아니라 이제까지 낮익은 자신과 주변을 일시에 끊고 얼굴 없는 사람들의 삶 속으로 들어간다는 것을 뜻한다. 그에게는 이름도 없고 특징도 없다."

7 “도피자는 도피 그 자체가 가장 주요한 활동이다. 이를테면 그는 주위에 위험을 전파할 수 있는 전염병의 보균자와 같다. 그러므로 스스로를 격리하여 위험이 가실 때까지 자신과 싸워야 한다."

8 “유배의 공간이자 망명의 공간".

9 “그랬다. 나는 산정에 올랐을 때 내가 자폐되어 있다는 답답증 때문에 가슴이 터질 것만 같았다. 그자들은 막강한 무력과 폭력을 쥐고 번성해가는데 죽은 벗들은 가족의 숨죽인 울음에 둘러싸여 얕은 땅 아래서 몰래몰래 썩어가고 있었다."
} 


\begin{abstract}
"When I came to Galmoe and then Han Yoon-hee's breath touched me, I got an opponent. Through her I am here specifically. It was not Oh Hyun-woo but No. 1444, who was stuck in solitary confinement, because I was only self-conscious about sticking to my past thoughts and actions with human dignity in order to maintain my vitality to survive under adverse conditions at that time. I am now returning to the world through my opponent." ${ }^{10}$ (황석영 Hwang Seok-yeong 2000:112)
\end{abstract}

Eighteen years ago, Oh Hyeon-woo felt 'answerable' in his life in Galmoe, but now he's restoring his true identity there. That's because he realized outside of Galmoe that his life was in another state of isolation. The summoning from Galmoe offers the opportunity to face up to Oh's memory that he has neglected. He thought himself someone who has been making a history, but his life was just in fact embroiled in a whirlpool of history. For him, the life is always something which makes him to act prior to think. Galmoe gave him chance to reflect on the nature of his act and what lies behind it. There is not a utopia separated from reality but a 'memory' itself that makes people think about reality through concrete distinctions. In this regard, Galmoe can be recognized as a materialized space from Han's letter.

The problem is that such a feature of Galmoe is just moment. At least for him, Galmoe is only a temporary space to stay in for his return to normal life. He is not perfect stay there in the past and now. That's because "life in Galmoe wasn't real life for Hyun-woo" 11 (권경미 Kwong Kyong-mi 2013: 218). But if it could provide him with a new starting point, where does the power begin?

Ironically, it is 'an absence of Han Yoon-hee'. In this piece, Han Yun-hee's function is Galmoe itself, but Galmoe can gain totality only when she is absent. Therefore, it is unjust to replace Han as a 'motherhood'. At least in this work, Han Yun-hee is not mythical as a mother. She did not live as a mother devoted to her daughter EunKyeol. Rather, she was free from her obsession with blood. Hwang Seok-young gives her the meaning of a 'one person' who lives her

\footnotetext{
10 “갈뫼에 와서 한윤희의 숨결과 접하면서 나는 상대방을 얻게 되었다. 상대를 통해서 나는 여기 구체적으로 존재한다. 독방에 처박혀 있던 것은 오현우가 아닌 천사백사십사번으로서, 악조건 속에서 살아남을 생명력을 유지하기 위해서는 과거의 생각과 행동을 사람의 존엄성으로 고수해야 한다는 자의식만 있었다. 나는 이제 상대를 통하여 세속의 길로 돌아오는 중이다."

11 ““갈뫼'에서의 삶은 ‘현우’에게는 현실이 아니었다.”
} 
own life. So she was not a mythical mother, but she was able to hug whole hurtful life to heart with love. She was life itself as a subject. But the problem is that Han's life is also outside of Galmoe.

So where is the real meaning of Galmoe? It is confirmed by Eun-kyeol. At this point, I want to point out the meaning of Oh's 18 years in prison. It is also the duration for Eun-Kyeol to grow overcome the parent's absence into a full human being. It changed the crossed absence of Oh Hyun-woo and Han Yoon-hee from The Old Garden to understandable. In their absence, Eun-kyeol had the chance to get possiblity of not losing her hometown even though she did not belong.

In this regard, Galmoe means 'sampo' a huge womb that cannot be restored. A place which is ready for birth, but never to stay. So it is Galmoe that can be completed only through the 'a vacancy' of someone's absence. It's another image of 'Sampo', a prototype of the world that was revealed in The Road to Sampo.

\section{Literary considerations on the divided system - The Guest}

The first significance of Hwang's return in The Old Garden, was the recall of stopped memories and the will to start specific reflection on the present. Thus, Galmoe has served as a place to recall and reason memories, rather than a utopian place that forgets everything.

The Guest, like The Old Garden, deals with the problem of 'return'. If The Old Garden considers for the 1980s, The Guest considers the 1950s. Both works are very similar in that they begin by recalling past memories, not present. Just as The Old Garden's narration begins in earnest with Oh's return to Galmoe, the story for The Guest begins with Ryu Yo-seop heading to Sincheon. This Sincheon of The Guest is another extension and origin of The Old Garden of Galmoe. This is because the present of the returnees who were alive but were absent (in their hometown) is a space prepared to face the memory of the dead.

Now The Guest's narration consists of a more full-fledged memorial rites. This novel was composed of twelve yards of 
Hwanghae-do's Jinogui-gut ${ }^{12}$. The work also faces the most sensitive issue of Korean modern history, called division, based on the murder of the massacre of innocent people in Sincheon ${ }^{13}$.

After the Korean War's armistice, the division that was supposed to be temporary and temporary became the reality of the public. The two regimes that formed on the Korean Peninsula were formed on the basis of acknowledging and acquiescing the division itself as a system. Therefore,

\begin{abstract}
"we have no choice but to admit that the division of the two Koreas has a significant continuity to take for granted the term 'separate era'. Before we know it, the system is not a single society where either side waits for a brief period of 'repelling' or 'emancipation' but it has become a complex being, not a mechanical union of the two

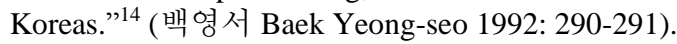

The narration of The Guest is shaped on the recognition of this system.

But inside it, Hwanghae-do is a very special place. The Korean Peninsula, which was divided into two Koreas based on the 38th parallel of the Northern Limit Line after the Liberation of Korea, changed its boundary to the Military Demarcation Line (a truce line) after the Korean war. As a result, there formed the Restored Area in South Korea, which is south of the 38th parallel and north of the truce line, and the New Liberation Area in North Korea, the southern part of the border (cf. Han Monica 2015: 234).

Almost New Liberation Area is in the south of Hwanhae-do. Typical areas include Ongjin-gun, Ganghwa-gun, Byeokseong-gun, Baecheon-gun, and Yeonbaek-gun. Sincheon was close to the new liberation area and also was on the boundary of 38th parallel. Therefore, we can guess that the region was more acute in inciting and confronting ideology than any other region.

\footnotetext{
${ }^{12}$ Jinogui-gut (지노귀굿): an exorcism ritual to send the souls of the dead into the sky.

${ }^{13}$ The Sincheon Massacre is a case that in October 1950 during the Korean War, about 35,000 civilians were massacred in Sincheon County, Hwanghae Province. There is still controversy over who is the perpetrator of the massacre, as the two Koreas are sharply divided over their claims. Hwang's The Guest interpreted the incident as a result of a ideological confrontation between the right and the left, which is not entirely explained.

14 “분단체제는 어느 한쪽이 잠시 ‘수복' 또는 '해방'을 기다리고 있는 단일사회도 아니요, 그렇다고 남북 두 사회를 기계적으로 수합한 개념도 아니다."
} 
The Guest examines the present and origin of the Korean Peninsula. It is a space where real power operates according to the divided system. Sincheon, the narratif stage of the novel, hometown to Ryu Yo-seop and his older brother Ryu Yo-yoon, is itself a symbol of all the violence and hidden memories surrounding the division. Therefore, writer Hwang Seok-young no longer describes idealized hometowns. Rather, he encourages the people to approach the actual hometown and summon the hidden memory. It is the beginning of rites that Ryu Yo-seop, a pastor in the U.S., visits his hometown of Sincheon, Hwanghae Province. But his return is not alone. Yo-seop is heading for his hometown to be possessed by gost of Ryu Yo-han, his old brother.

\footnotetext{
"Yo-seop pressed back Yo-han's phantom and sat on seat. Yo-seop, Yo-seop. He quickly lifted his hips in surprise and sat down again. Yo-seop mumbled in his mouth. Don't do anything stupid. That's it. Why do you keep showing up? I'm going home with you, too." 15 (황석영 Hwang Seok-yeong 2001: 37-38)
}

Yoseop's home visit is not just a nostalgia, but a clear goal of settling old grudges. But the subject is his old brother Yo-han. More precisely, his old brother Yo-han meets the ghosts of the men he murdered in Sincheon. And the narration of The Guest is developed directly through their conversations and memories. Here, Ryu Yoseop serves as a living memory medium that records the dissolution of the dead, not a returner. For this reason, the actual return of the work is the specter of Ryu Yo-han. In other words, the story is told as a Jinogui-gut performed by ghosts who died in a real space rented by a living person.

Then why should reconciliation be made from ghosts? It is worth noting that the story of The Guest began from the beginning with the death of the real return, Ryu Yo-han. It is the first key to reading this novel. Only ghosts that have escaped from life can be free from all restrictions that come from real life conditions. Ryu Yo-han, the main culprit of the massacre, had strived to cover-up his history of madness and violence completely through his whole life. It was the

\footnotetext{
15 “요한 형의 환영을 등으로 깔아뭉개면서 요섭은 등받이에 푹 기대앉았다. 요섭아, 요섭아. 그는 깜짝 놀라서 궁둥이를 얼른 들었다가 다시 앉았다. 요섭은 입속으로 중얼거렸다. 허튼 짓 하지 말라우요. 한번 갔으문 그만이지 왜 자꾸 나타나구 기래요? 나두 너하고 고향 가볼라구."
} 
only way for him to maintain a normal or normal life. Therefore, real isolation from reality was essential to clarify the hidden truth surrounding the massacre.

"-You...... look like to meet the reds.

Yo-han, like an old man living alone, glanced at him with a suspicious, not a welcome expression."16 (황석영 Hwang Seok-yeong 2001: 12)

Before his death, Yo-han showed suspicion and displeasure when he found out that Yo-seop was visiting his hometown in North Korea. Above all, he wanted to remember the incident in Sincheon as a holy war. The total anti-Communism and attachment to Christianity that appears in Yo-han is more like a cover-up effort to escape this sense of guilt. His life was still not free from his misdeeds and guilt.

This Yo-han's life reflects our attitude toward the division. For the past half century, the two Koreas have been at odds with each other, with their memories of violence and damage mixed. At least, in the Korean Peninsula, 'the division' is clearer to be cognized as 'system' rather than 'ideology'. Without overcoming this system, it is impossible to reflect on and to further reconcile. So it is perhaps inevitable that Yo-han will die before going home.

In the story of The Guest, the touch of reconciliation is not from return but from death. Yo-han's death was also predicted through Sun-nam's ghost who was killed by him. His hometown, where all memories were buried, called him. Yo-han's little bone that Yo-seop has unwittingly cherished is an essential element to open this huge altar. Yo-seop's homecoming is not his own, but is clearly for the dead Yo-han. Yo-han's death was a prelude to this return.

At this point, the title 'the guest' is contradictory. Hwang Seok-yeong said (2001: 261) that "Christianism and Marxism are imperfect modernity that we have not achieved self-sustaining modernization through colonies and divisions" ${ }^{17}$. But contrary to Hwang's intentions, the truth revealed in The Guest says the origin of the nightmare is within us. In fact, "the most crucial thing in the history of the massacre was land reform" 18 (이재영 Lee Jae-yeong

\footnotetext{
16 “너 ...... 빨갱이들하구 만나는 모낭이로구나." 형은 반가운 표정은커녕 혼자 사는 늙은이답게 의심이 가득 찬 눈길로 요섭을 흘겨보았다."

17 “기독교와 맑스주의는 식민지와 분단을 거쳐오는 동안에 우리가 자생적인 근대화를 이루지 못하고 타의에 의하여 지니게 된 모더니티"라고 규정하였다." 18 “학살의 전사에서 가장 결정적으로 제시되는 것은 토지개혁"
} 
Suyun RYU: East Asia, the Restoration of Memories...

2003: 109). The actual command of the small civil war in Sincheon Chamsaem-gol was an economic logic disguised as a 'guest' represented by Christianity and Marxism.

\begin{abstract}
"How long did you think you'd take our land away from us, you son of a bitch.

I could hear Yo-han talking and felt someone tried to stop him.

This son of a bitch was the head of the land reform committee for army. I don't want to kill him comfortably." ${ }^{19}$ (황석 영 Hwang Seokyeong 2001: 213)
\end{abstract}

The crime of Il-rang that Yo-han shouts is not Christian repression. Il-rang's crime was that he was the head of the land reform committee for army. The motive for the massacre was economic logic, not religion or ideology.

\begin{abstract}
"God, Father, I have kept my faith under the oppression of the Communist Party, the enemy of the Holy Spirit. (......) You said our fight is not about blood and flesh, but against corrupt power and the evil spirit of Satan. The only way we can win this battle is to rely on God's power, use his weapon for this war, and prepare ourselves. Now that the Crusades are near us, which will liberate our brothers by faith, but the Satan army is still threatening us. (......)

While the prayer ended and raised their faces, young people were heated with hatred and hatred for Satan, just as their bodies were engulfed by the flame of the Holy Spirit."20 (황석영 Hwang Seokyeong 2001: 203)
\end{abstract}

The moment the massacre takes over the religious aspect of the holy war, madness becomes uncontrollable. Here, the "Yo-han's idea that defines the war against the socialists as a holy war is in line

\footnotetext{
19 “너 이새끼 우리 땅 뺏구 천년만년 리당위원장 해먹을 줄 알았네? 요한이 말이 들레오구 곁에서 말리넌 소리두 들리두만. 이새끼 군 토지개혁위원장 지냈디. 펜하게 쥑여선 안되가서."

20 “하나님 아부지 저이넌 성령으 적인 공산당으 압제럴 받으멘서 믿음얼 지케왔습네다. $(\cdots)$ 우리 싸움언 피와 살에 대한 것이 아니오 정사와 권세와 이 어둠의 세상 주관자덜과 사탄이라넌 악령에 대한 싸움이라 하셨습네다. 우리가 이 싸움에서 이길 수 있넌 유일한 방법언 하나님으 능력얼 으지하고 이 전쟁얼 위해 하나님으 무기럴 사용하며 우리 자신얼 준비시키는 것입네다. 이제 자유으 십자군덜이 저이 믿음으 형제덜을 해방하려고 지척에 왔으나 사탄으 군대넌 아직도 저이럴 위협하고 있습네다. ( $\cdots)$ 기도를 드리고 얼굴을 들자 청년들은 온몸이 성령의 불길에 휩싸이는 것처럼 사탄에 대한 증오와 혐오감이 뜨겁게 달아올랐다."
} 
with the idea of witch hunting."21 (양진오 Yang Jin-oh 2001: 1231). Religion was used as a justification for violence, and collective insanity was tolerated under the name of the holy war.

"I thought our 'social splitting' was over. It is no longer the Lord's crusade to destroy Satan. I thought that we began to cost test and faith was corrupt. (.....) When we were a little annoyed, we cursed and killed our opponents." 22 (황석 영 Hwang Seok-yeong 2001: 246).

Uncontrollable madness. 'The division', and 'the system of division', by itself, has eaten into our modern history with insanity. The reason why a living Yo-seop had to exist only as a recording medium is also stated here. It is because Yoseop is a 'living person' within the system, and it is impossible for him to judge the division outside the system.

Finally, the ghost's story closes, and Yo-seop burns dead Yohan's clothes and hides his bones in the land where he was born. This concludes Yo-han's long and arduous return. But as a recording medium and a remembering self, Yo-seop's true meaning is discovered later on. Yo-seop did not consider himself to be the perpetrator of the massacre. Yo-seop's attitude is as like that we are today looking at the division and divided system. Even though we are in the system, we are either ignorant or neglectful of its responsibilities.

Hwang Seok-young asks us through Yo-seop: can we really be free from this nightmare? There is only one truth that Yo-seop encountered in Sincheon. At the moment of the brutal massacre, he was there too.

The ghosts went down, and the survivors prepared themselves to clean up the nightmare of reality. How will Hwang solve this era of reconciliation and coexistence? His narrational journey now leads readers to 19th century East Asia through Sim-cheong. Because he takes issue with yesterday's 'memory' that made it possible for him to return, not today.

\footnotetext{
21 “요한의 발상법은 바로 마녀 사냥의 발상법과 상통"

22 “나는 이제 우리의 편먹기는 끝났다고 생각했다. 더이상 사탄을 멸하는 주의 십자군이 아닌 것이다. (......) 조금만 짜증이 나면 에이 썅, 하고 짧게 씹어뱉고 나서 상대를 죽여버렸다."
} 
4. Return of the Discourse and Translated 'Joseon' in East Asia- Sim-Cheong

The previous two return narration recalls the essential meaning of Hwang's return project in the 2000s. It was a recall of memories and a reconciliation with the present through such recall. Ultimately, it was an attempt to reflect on our modern history from the beginning. And now in Sim-Cheong, he comes back to the very beginning of the modern era. He now tries to explain the essence of 'the guest' as a 'transplanted modernity'.

Hwang's Sim-Cheong parodies the familiar tale, Simcheongjeon, while betraying. Sim-Cheong, more than anything, begins by removing the narrative formula that is hung by this character. The author removes the anura of filial piety from Sim-Cheong. The filial piety of filial piety, which was voluntarily sacrificed for blind father, no longer exists. Only a poor Joseon girl, Sim-cheong, had to be sold for a few bucks amid her stepmother's greed and father's neglect. Hwang's Sim-Cheong translates the theme of Simcheong-jeon into 'forced sacrifice' or 'exploitation'.

A girl who has nothing is now thrown naked into a society of modernity. She chooses her own way of becoming a commodity to survive. For this, Sim-cheong goes through symbolic death as a human sacrifice. She separates her soul 'Cheong-i' from her own body. Therefore, she could stand the journey of prostitution. She was reborn as a substance through the symbol of death.

The characteristics of Hwang's story of return are repeated in Sim-Cheong. It went through the gateway of death and leads back to the 'empty absence'. But after the spirit of 'Cheong-i' was separated from her body, Sim-cheong was virtually absent in this story. She is always shaped by other people's eyes rather than by herself. Like all the names (Ren-hwa, Lotus, Renka) she had, she was always defined by others. That is because Sim-cheong is not just an individual here, but a person who literally portrays the realities of East Asia that are turning into a colony.

Sim-cheong was transformed from a simple country girl to a prostitute, from an old Chen lady to a local mistress of an English businessman, to a royal wife and a fairy maestro. All her journeys symbolize the encounter of imperialism among East Asian countries. Therefore, Sim-cheong's wandering gives us a fascinating experience 
of "the diverse landscape of East Asia that has entered modern times."23 (서영채 Seo Yeong-Chae 2004: 2). The personal journey of Sim-cheong follows the historical transformation process of East Asia and modern times.

If The Old Garden and The Guest dealt with the aftermath of a reconciliation with the past, Shim cheong aims to describe at the long and arduous return of a Joseon-era girl. From this point of view, the phrase "the Ulysses record of a far-off return" 24 (최원식 Choi Wonsik 2001: 47) attached to The Old Garden seems to be more appropriate for Sim-Cheong.

As such, the fate of Sim-cheong is terribly violent. Simcheong was not allowed any image of 'comfort'. Sim-cheong herself did not lament or frustrate her humble life under any circumstances. She overcame the most desperate moment with her strongest life.

" - Now that the old man is dead, Lenhwa's role has ended.

But I can't go back to Cheong-i.

Lenhwa whispered inside Cheong-i. It was a world that she had already left, like the remote underworld blocked by the high seas of the deep, blistering waters. "25 (황석 영 Hwang Seok-yeong 2003: 58)

Next to the deceased Chen, Sim-cheong thinks of her fate. She realizes that her role as an old Chen's waiting servant is over, but she can't go back to 'Cheong-I'. Because she had chosen to live as Lenhwa with a weapon of 'body'.

As such, Sim-cheong divides herself constantly, achieving the goal of 'survival' through violent fate and painful compromise. Simcheong's choice to become a 'Lenhwa' rather than 'Cheong-i' was inevitable in order to protect her during the long, long journey of rape. She didn't abandon 'Cheong-i' she hid 'Cheong-i' in order to protect 'Cheong-i'.

"I'm going to swallow them all. Okay, let's just hang in there. I'll knock them down one by one. (...) She turned her head sideways and

\footnotetext{
23 "근대로 진입하는 동아시아의 다양한 풍경"

24 "머나먼 귀환의 율리씨즈적 기록"

25 "노인이 죽었으니 렌화의 역할도 끝나버린 것이다. 하지만 청이로 돌아갈 수는 없어. 청이의 몸 속에 함께 살게 된 렌화가 속삭였다. 그건 저 컴컴하고 물보라치던 높은 파도의 바다로 가로막힌 아득한 저승처럼 이미 떠나온 세상이었다."
} 
opened her mouth half-open, but she never closed her eyes." 26 (황석 영 Hwang Seok-yeong 2003: 174)

Sim-cheong's effort not to be frustrated by her own fate is surprisingly strong. In addition, Sim-cheong accepts fate, but never wants to settle for it.

\begin{abstract}
"-I want to go back to Dansui.
James suddenly threw a cigar into the yard and screamed.

-Oh, damn it! Are you saying that? I rescued you from the ditch and made you a lady. And I was going to marry you and to make you a legal wife. By the way, are you going to go back to Dansui's whore?

Cheong-i screamed too.

-Hey James, you're a merchant. We got a contract. You paid me and hired me. Don't you know Baozi? When the deal's over, you either pay back or you're looking for another woman."27 (황석영 Hwang Seok-yeong 2003: 56)
\end{abstract}

Sim-cheong's hardships in this novel resemble the history of exploitation in Joseon and East Asia. Sim-cheong sometimes compromised with fate and sometimes actively faced it. Hwang tried to pay attention to any possibility of our history through Sim-Cheong. Therefore, self-division of Sim-cheong is very intentional. The harsh fate given to Sim-cheong prevented her from finally returning to the 'Cheong-i'. However, her willingness to protect her identity as a 'Cheong-i' led her to become a more mature human being than 'Cheong-i'.

Hwang Seok-yeong throws a task at Korean. If the invincible history of colonization was our destiny, everything can no longer be solved by hanging on in the past and appealing for injustice. What are we doing to preserve our own identity from the 'the guest' of foreign ideology? The problem returns to Sim-cheong. Hwang requires

\footnotetext{
26 “내가 저들을 다 삼켜버릴 거야. 그래, 조금만 참자. 저들을 차례차례 쓰러뜨릴 테니까. ( $\cdots$ ) 청이는 고개를 옆으로 돌리고 입을 반쯤 벌려 숨을 내뿜고 있었지만 절대로 눈은 감지 않았다."

27 “단수이로 돌아가고 싶어요.” 제임스가 갑자기 시가를 마당으로 내던지며 소리를 질렀다. “이런 젠장할, 그걸 말이라구 하는 거야? 나는 시궁창에 빠진 너를 건져다가 숙녀를 만들어주었어. 그리고 결혼해서 정처 자리까지 주려고 했단 말야. 그런데 너는 지금 단수이의 창녀로 돌아가겠단 말이지?" 청이도 소리를 질렀다. "이봐 제임스, 너는 장사꾼이야. 우린 계약을 했어. 당신은 내게 급여를 주고 나를 고용한 거야. 바오쭈도 몰라? 계약이 끝나면 당신이 다시 돈을 내고 재계약을 하든가 아니면 다른 여자를 찾는 거야."
} 
readers outside of the text to find meaning of missing Sim-cheong within Sim-Cheong. Who is Sim-cheong?

Sim-cheong is a mother figure whom he wanted to recover from The Old Garden. Hwang Seok-young breaks the old model of motherhood through Sim-cheong. Sim-cheong has never had a baby, but she became a mother. She raised dead co-workers' children and built a house for biracial children of whores. No, in order to be a mother, she was more daring to compromise with her fate.

Hwang does not translate this Sim-cheong's behavior into a fancy formula. So the process of her becoming a mother is so natural. Because it's the underlying love, which every human has, for another human being. This seems to be the face of Hwang's new motherhood.

As soon as Sim-cheong becomes a 'motherhood' herself, she becomes one who can escape the yoke of fate that led her. Finally, now she can choose her own destiny. Through this maturity of Simcheong, Hwang shows a deep reflection on a human being who protects herself against the harshest of fate.

\section{Conclusion}

Finally, writer Hwang Seok-young returned to Korean society in name and substance with return trilogy. The return trilogy was about recalling and reflecting memories, seeking reconciliation with the present through the past, and at the same time closing the last century, which was horribly violent. The final piece of the trilogy, ShimCheong, ended its return and threw a new topic, 'Modern of East Asia'.

So how does the basic meaning of Hwang Seok-young's return come together? The first is the confusion of identity. The Korean society, which was absent for 10 years, became a stranger to him because that decade was the most rapidly changing time in Korean society. So second, he have got the subject of meeting his absence. That naturally leads to the third, the right to think of the changed 'today'.

But his return was not a conclusion, but a beginning, and was actually another topic. The question is caused from Sim-Cheong, the finale of the return trilogy. Why did the writer leave Sim-cheong on 
the narrow peninsula and throw her into the middle of world history? So, did we all find 'Joseon' and Korea through Sim-cheong?

We were able to discover the world of modern East Asia through the journey of Sim-cheong. But Sim-cheong, who returned to Joseon, was not a true returner. Still, she is typed not 'Sim-cheong' but 'Yeonhwa Bodhisattva'. Although Sim-cheong tried to protect her identity as a 'Cheong-i', she was unable to reconcile with her absence.

The meaning of Sim-cheong's return here must be corrected. She did not return to her hometown to return to 'Cheong-i'. It is to confirm the death of 'Cheong-i' through her stomach and recognize 'Sim-cheong' as another self, who has been called by her numerous names. That is to end the journey of long division.

Hwang adapted the filial piety and sacrifice of Simcheongjeon into exploitation. 문재원 Mun Jae-won (2006: 354) states that "Prostitution in Sim-Cheong is a mirror of modern systems that evoke the violence of modernization surrounding East Asia in the 19th century." 28 . Shim-Cheong, however, is the end of this long journey, the actual beginning and limitation of the author Hwang's return.

He gave Sim-cheong the possibility of a special motherhood, but for that very purpose, Sim-cheong always existed as a symbol, not as an individual. Furthermore, all the violence against Sim-cheong was not properly repented. But if Sim-cheong could be the beginning, because she was the one who won her own 'life'. The meaning of the 'start' can be more pronounced by comparing it with the sequel Baridegy. I did not make Baridegy the text of full-fledged discussion in this paper. I think there will be a chance to discuss the work in relation to Hwang Seok-young's other work, The Gaebbabbaragi Star. Discussions on this are left to the task of the future.

\section{Bibliography}

강용훈 (Kang Yong-hoon). 2007. 황석영 장편소설에 나타난 귀환의 의미 Hwang Seok-yeong jangpyeon soseol-e natanan gwihwan-ui uimi (A Study on the meaning of the returning in Hwang Suk-Young's Novel). 한국문예비평연구 Hangug

28 “『심청』에 나타난 매춘은 19 세기 동아시아를 둘러싸고 있는 근대화의 폭력성을 환기시키는 근대 제도의 거울인 셈이다." 
Munyebipyeong yeongu (Korean Literary Review). 24: 259283

권경미 (Kwon Kyong-mi). 2013. 지식인 주체의 생존 현실 인식과 저항의 서사 Jisigin juche-ui saengjon hyeonsil insig-gwa jeohang-ui seosa (The Recognition of Survival Reality of Intellectuals subject and the Narrative of Resistance), 한국문예창작 Hangug Munye Changjag (Korean Literary Creative Writing) 12-1: 207-235.

남진우 (Nam Jin-woo). 2000. 돌의 정원: 황석영 소설과 알레고리적 상상력 Dol-ui jeongweon: Hwang Seok-yeong soseol-gwa allegorijeog sangsangryeog (Stone Garden: Hwang Seok-yeong's Novel and Allegory Imagination), 문학동네 Munhakdongne 2000, vol. 7 (3): 1-19.

문재원 (Mun Jae-won). 2006. 황석영의 "심청"의 근대성과 탈근대성 Hwang Seokyeong-ui Simcheong-ui geundaeseonggwa talgeundaeseong (A Study on Soggyung Hwang's Shim Chong's modernity and post-modernity), 한국문학논총 韓國文學論丵 Hangug Munhag Nonchong (Korea Publications) 43: 351-375.

백영서 (Baek Yeong-seo). 1992. 분단체제의 인식을 위하여 Bundan cheje-ui insig-eul wihayeo (For the Recognition of the Divided System), 창작과비평 Changjag-gwa Bipyeong (The Quarterly Changbi) 1992, Winter: 288-309.

서영채 (Seo Yeong-chae). 2004. 창녀 심청과 세 개의 진혼제 Chanyeo Simcheong-gwa se gae-ui jinhongje (Simcheong as a Prostitute and Three Repose of Souls), 문학동네 Munhakdongne 2004. Vol. 11 (1):1-15.

양진오 (Yang Jin-oh). 2001. 해원하는 영혼과 죽어가는 노인들 황석영의 “손님” 과 김원일의 „슬픈 시간의 기억, Haeweon-haneun Yeonghon-gwa jugyeoganeun noindeul Hwang Seok-yeong-ui "Sonnim"-gwa KimWeon-il-ui "Seulpeun sigan-ui gieog (The Miseries of the Soul and the Dying Old Men), 문학과사회 Munhag-gwa Sahoe (Literature \& Society), 2001. Vol. 14 (3): 1229-1238.

오생근 (Oh Saeng Geun). 2003. „오래된 정원” 과 시간을 이기는 사랑의 힘 „Oraedwen Jeongweon”-gwa siganeul igineun sarang-ui him (The Old Garden and the Power of Love over Time), In: 황석영 문학의 세계Hwang Seok-yeong Munhagui segye (The World of Hwang Seok-yeong's Novel), 
Suyun RYU: East Asia, the Restoration of Memories...

최원식·임홍배 편 (Choi Won-sik \& Leem Hong-bae)(eds.), pp. 81-99. Seoul: 창비 Changbi.

오태호 (Oh Tae-ho). 2005a. 오래된 서사 Oraedwen Seosa (An Old Narrative), Seoul: 하늘연못 Haneul-yeongmot.

오태호 (Oh Tae-ho). 2005b. 황석영 소설에 나타난 이데올로기적 주체의 변화 양상 고찰 Hwang Seok-hyeong soseol-e natanan ideollogijeog juche-ui byeonghwa yangsang gochal (A Study for changing of 'Ideologic subjects' in Hwang Seokyoung's Novels), 국제어문 Gugje Eomun (International Language and Literature) 33: 263-291.

이재영 (Lee Jae-Yeong). 2003. 진실과 화해 - ,손님"론 Jinsil-gwa hwahae - „Sonnim”-ron. In: 황석영 문학의 세계 Hwang Seok-yeong Munhag-ui segye (The World of Hwang Seokyeong's Novel) 최원식·임홍배 편 (Choi Won-sik \& Leem Hong-bae) (eds.), pp.100-116. Seoul: 창비 Changbi.

최원식 (Choi Won-sik). 2001. 나와 우리, 그리고 세상 Na-wa uri, geurigo sesang (I, We, and World), 창작과비평 Changjaggwa Bipyeong (The Quarterly Changbi), 2001, vol. 3: 36-59.

한모니까 (Han Monica). 2015. 남·북한의 '수복시구'와 '신해방지구, 편입 비교 Nam-Bukhan-ui subogsigu-wa sinhaebang jigu pyeonib bigyo (A Comparison of the Integration of the "Newly Liberated Areas" and "Retaken Areas" in North and South Korea), 동방학지 Dongbang Hagji (The Journal of Korean Studies) no.170: 233-264.

황석영 (Hwang Seok-yeong). 2000. 오래된 정원 Oreadwen Jeongweon (The Old Garden) (1). Seoul: 창비 Changbi.

황석영 (Hwang Seok-yeong). 2000. 오래된 정원 Oraedwen Jeongweon (The Old Garden) (2). Seoul: 창비 Changbi.

황석영 (Hwang Seok-yeong). 2001. 손님 Sonnim (The Guest). Seoul: 창비 Changbi.

황석영 (Hwang Seok-yeong). 2003. 심청 (Sim Cheong) (1). Seoul: 창비 Changbi.

황석영 (Hwang Seok-yeong). 2003. 심청 (Sim Cheong) (2). Seoul: 창비 Changbi. 